\title{
Semper's (zoanthid) larvae: pelagic life, parentage and other problems
}

\author{
J. S. Ryland ${ }^{1}$, Samantha de Putron ${ }^{1,2}$, R. S. Scheltema ${ }^{3}$, P. J. Chimonides ${ }^{4}$ \& D. G. Zhadan ${ }^{5}$ \\ ${ }^{1}$ University of Wales Swansea, Swansea SA2 8PP, U.K. \\ ${ }^{2}$ Bermuda Biological Station for Research, St Georges, Bermuda \\ ${ }^{3}$ Woods Hole Oceanographic Institution, Woods Hole, MA 02543, U.S.A. \\ ${ }^{4}$ Natural History Museum, London SW7 5BD, U.K. \\ ${ }^{5}$ Department of Invertebrate Zoology, Moscow State University, Moscow 119899, Russia
}

Key words: larval types, distributions, sea temperature, zooxanthellae, deep sea, Epizoanthus

\begin{abstract}
Semper's larvae were obtained from $<300$ out of $\sim 1800$ plankton tows taken in the world's oceans (1964-1993). Zoanthellae (larvae of Sphenopidae) occurred at 217 stations and zoanthinae (larvae of Zoanthidae) at 86, the two larval types showing distributions clearly delimited by a minimum sea temperature $\left(\sim 22{ }^{\circ} \mathrm{C}\right.$ for zoanthellae, $\sim 18{ }^{\circ} \mathrm{C}$ for zoanthinae; a statistically significant difference, $\left.P<0.001\right)$. Length of formalin-fixed zoanthellae was $\sim 2-8.6 \mathrm{~mm}$ and of zoanthinae $\sim 1.5-5.9 \mathrm{~mm}$. Endodermal zooxanthellae were present in $9 / 24$ zoanthinae but in no zoanthellae (of 19). Three larvae contained an endo-commensal/parasitic amphipod. Septa were externally visible in larger zoanthinae and were counted in transverse sections of other larvae, a majority of which (both kinds) had 12 septa, the normal maximum. The pattern was brachycnemic in 40/43 larvae and anomalous (but nonmacrocnemic) in three. If macrocnemic genera reproduce by Semper's larvae, they should have been represented in such a large sample. The distribution of adult Epizoanthus was examined: many species are deep sea (recorded down to $\sim 5000 \mathrm{~m}$ ) but shallow-water species are relatively plentiful in, for example, the Adriatic and North Seas. No Semper's larva has ever been recorded from either. Some Parazoanthus species also occur in shallow water, especially associated with western Atlantic reef sponges. If they produce Semper's larvae, these have never been found. It is probable that macrocnemic zoanthids settle from planulae that do not develop into recognizable zoanthellae or zoanthinae.
\end{abstract}

\section{Introduction}

Semper's larvae are named from their discoverer (Semper, 1867), who identified them only as belonging to Anthozoa. He found two different kinds: the first was a $6 \mathrm{~mm}$, almost cylindrical planula with a long, midventral ciliary band extending from the blastopore much of the distance to the anterior pole; the second was smaller, ovoid, with an equatorial ciliary band. Semper (1867) suggested that the second larva might be an earlier stage of the first. His 'first' larva was obtained from the Moçambique Current, off the Cape of Good Hope $\left(42^{\circ} \mathrm{S}\right)$ and off the south coast of Java. Two further specimens were obtained south of the Cape Verde islands by the German Plankton Expedition, one of which was fully described by van Beneden (1890), who later (1897) named it Zoanthella. Van
Beneden (1897) also described a specimen of Semper's 'second' larva, taken from the Guinea Current, naming it Zoanthina, and similar larvae, from off Beaufort, North Carolina, were examined by McMurrich (1891). Both authors (Van Beneden 1890, 1897; McMurrich, 1891) recognized Semper's larvae as zoanthids. Van Beneden's terms have remained in use as the names of larval types but not of genera.

Zoanthids (order Zoanthidea) are distinguished and classified according to the arrangement of the internal septa (Fig. 1). Appreciation of this is necessary to follow the arguments in this paper. In all Anthozoa, septa which reach the actinopharynx or (below it) bear a thickened 'filament' are termed 'perfect'; septa which neither reach the actinopharynx nor bear a filament are 'imperfect'. Polyps and larvae display biradial symmetry and septa which constitute mirror 


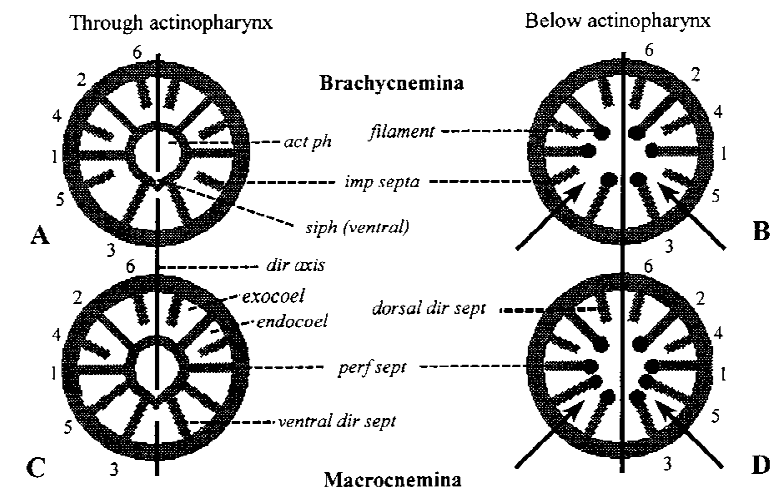

Figure 1. Septa and the classification of zoanthids. Diagrams are cross-sections through larvae or embryos at the 12-septa stage of development (at which the diagnostic patterns first become apparent). The numbers 1-6 indicate the sequence of septal formation, the state of the fifth couple (imperfect or perfect) being diagnostic for Brachycnemina and Macrocnemina, respectively; further septa are added in the proliferation chambers (ventro-lateral exocoels), marked by the solid arrows, on each side of the ventral directive septa. The upper diagrams (A, B) represent Brachycnemina, the lower pair (C, D) Macrocnemina; the left-hand diagrams (A, C) are cut through the actinopharynx, the right-hand pair $(\mathrm{B}, \mathrm{D})$ below the actinopharynx; perfect septa bear filaments (shown black) at this level. The solid vertical lines mark the directive axes: left and right sides are mirror images, opposite septa being termed couples. Spaces between directive couples, and ventral to perfect septa (except for the fifth couple in Macrocnemina) are endocoels; spaces ventral to imperfect septa (and to the perfect fifth couple in Macrocnemina) are exocoels. Act ph, actinopharynx; dir axis = directive axis; dir sept $=$ directive septum; imp sept $=$ imperfect septum/septa; perf sept $=$ perfect septum/septa; siph $=$ siphonoglyph .

images comprise 'couples'. The couples which border the axis of symmetry ('directive axis') are 'directive' septa. In zoanthids, the dorsal directives are imperfect and the ventral directives perfect; the remainder, with the exception of the fifth couple (counting from the dorsal directives), are alternately perfect and imperfect. As established by Erdmann (1885), the fifth couple may be either 'macrocnemic' (perfect: suborder Macrocnemina Haddon \& Shackleton, 1891) or 'brachycnemic' (imperfect: suborder Brachycnemina Haddon \& Shackleton, 1891). Septa first appear in the developing larvae; small larvae contain six septa, larger ones contain 12. McMurrich (1891) and Van Beneden (1897) established that the arrangement of internal septa in their larvae corresponded to the brachycnemic pattern, but disagreed somewhat over the sequence of their development.

Menon (1902, 1914, 1926) settled the developmental sequence of septa in the larvae (numerals 1-6 in Fig. 1) and established which genera reproduce with a zoanthella (Sphenopus, Protopalythoa), and which with a zoanthina (Isaurus, Zoanthus). Kimura et al. (1972) later added Palythoa to the former group. These are all brachycnemic genera but form two natural groupings on another ground: the former (with a zoanthella) incorporate sand into their mesogloea, the latter (with a zoanthina) do not. Sand incorporation was recognized by Gray (1867) as a significant character, but in recent years - despite the correlation with larval type - both groups have been inappropriately united within the family Zoanthidae. Here, Sphenopidae Hertwig (1882) is reinstated to distinguish the former.

Carlgren (1923) sectioned Isozoanthus giganteus and found that it brooded embryos which clearly displayed the macrocnemic pattern, with the 5th couple perfect at the 12-septa stage. Studied species in the macrocnemic genera Epizoanthus (Muirhead et al., 1986) and Parazoanthus (Ryland, unpub.), on the other hand, have proven oviparous, although no corresponding macrocnemic larvae have ever been found. Zoanthid reproduction generally has been reviewed by Ryland (1997).

Important results have accrued from Scheltema's $(1968,1971,1989)$ studies of the occurrence of larvae, including zoanthellae and zoanthinae, of shoal-water benthic invertebrates in the oceanic plankton. First for the Atlantic (Scheltema, 1968) and then for the Pacific (1989), Scheltema showed that the larvae ranged eastwest right across the oceans (in the Pacific, the only larval group in his study not to show significant reduction east of longitude $160^{\circ} \mathrm{W}$ ), but that they were restricted to warm low latitude waters. There are now many more samples, especially from the Atlantic, than when the earlier papers were written and the entire collections of Semper's larvae obtained between 1952 and 1993 form the basis of the present paper. Our objectives are: (1) to analyse and compare the distribution patterns of these larvae in the surface waters of the world's oceans; (2) to study in them the occurrence and distribution of zooxanthellae; and (3) to investigate why, roughly a century after Van Beneden's and Menon's first papers (Van Beneden, 1890; Menon, 1902), larvae of zoanthids having macrocnemic septation are - as at the end of the nineteenth century (Carlgren, 1906) - still unknown.

\section{Materials and methods}

Nearly 1800 successful plankton samples were taken on almost 60 cruises between 1952 and 1993. Collec- 


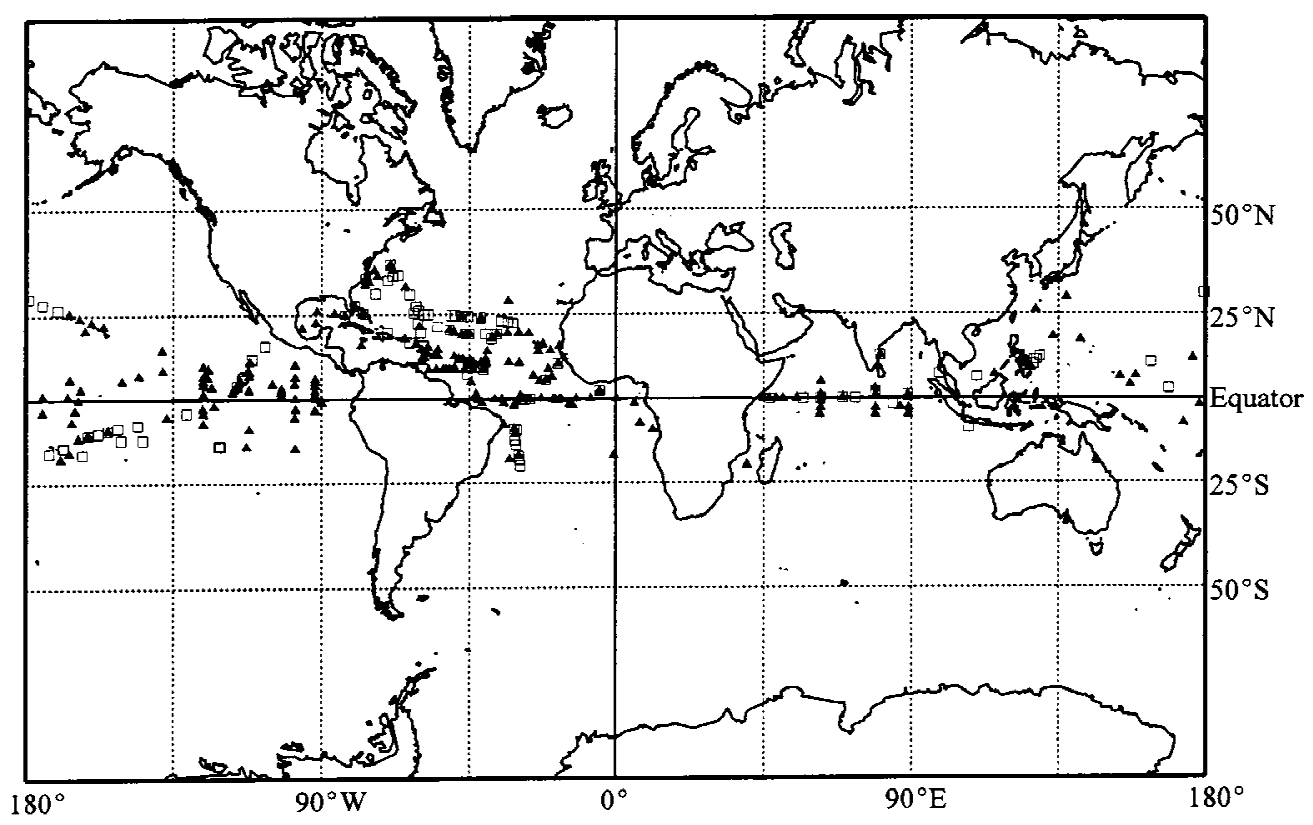

Figure 2. Occurrences of Semper's larvae in the world's oceans, including the few known from earlier literature ( $\boldsymbol{\Lambda}$ zoanthella, $\square$ zoanthina).

tion and sample sorting methods have been described elsewhere (Scheltema, 1968, 1971, 1986, 1989). Exact procedures varied slightly between vessels of different operators, but sea surface temperature and depth were generally recorded by Woods Hole Oceanographic Institution (WHOI) ships. Tows were oblique and generally sampled from a depth of $100-150 \mathrm{~m}$ to the surface. Larvae for sectioning were drawn, or photographed using dark field illumination under a Wild M20 Makroskop, and measured with a micrometer eyepiece. Sections were cut at 7 or $8 \mu \mathrm{m}$ (some at WHOI at 5 and $10 \mu \mathrm{m}$ ), and stained with haematoxylin and eosin or Mallory's triple. Since many of the specimens had been in preservative for decades, and were expected to be either soft or brittle, a double embedding technique was used at Swansea. Specimens were dehydrated in ethanol and then soaked for $24 \mathrm{~h}$ through two changes of necoloidine solution before being cleared in chloroform. Embedding in molten paraffin wax was repeated in four changes to ensure complete penetration before cooling the block ready for sectioning. Sections were examined primarily to determine the numbers, types and arrangement of septa, and the absence/presence and distribution of zooxanthellae, but the amount of yolk in the coelenteron, the state of the cell layers, and the thickness of the mesogloea proved highly variable and were recorded.

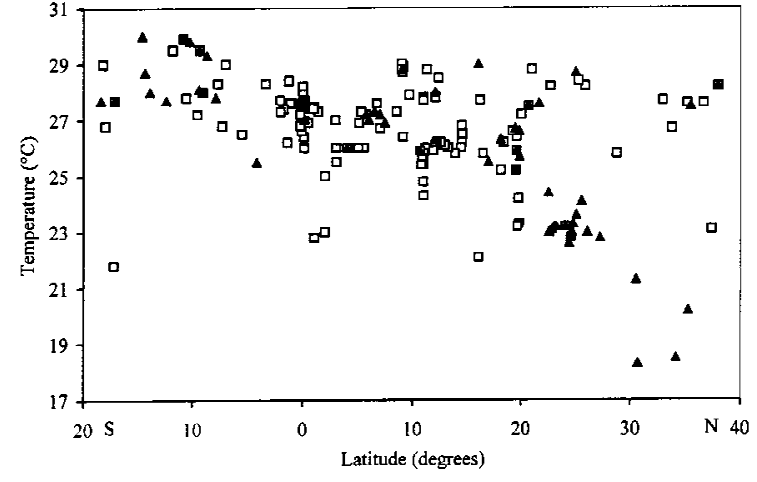

Figure 3. Temperature distribution of Semper's larvae ( $\Delta \mathrm{zo}-^{-}$ anthella, $\square$ zoanthina).

Cruise and station details were entered into a database. A few additional records have been obtained from the literature. Collection coordinates (latitude and longitude converted to decimal degrees) have been used for map compilation and distributions have been correlated with sea surface temperature when available.

The principal macrocnemic genera are Epizoanthus and Parazoanthus. The former is better known because, though both tend to be commensal, adult Epizoanthus colonies are associated with molluscs (especially living neogastropods); with pagurid crabs, with which they form carcinoecia, replacing the ori- 


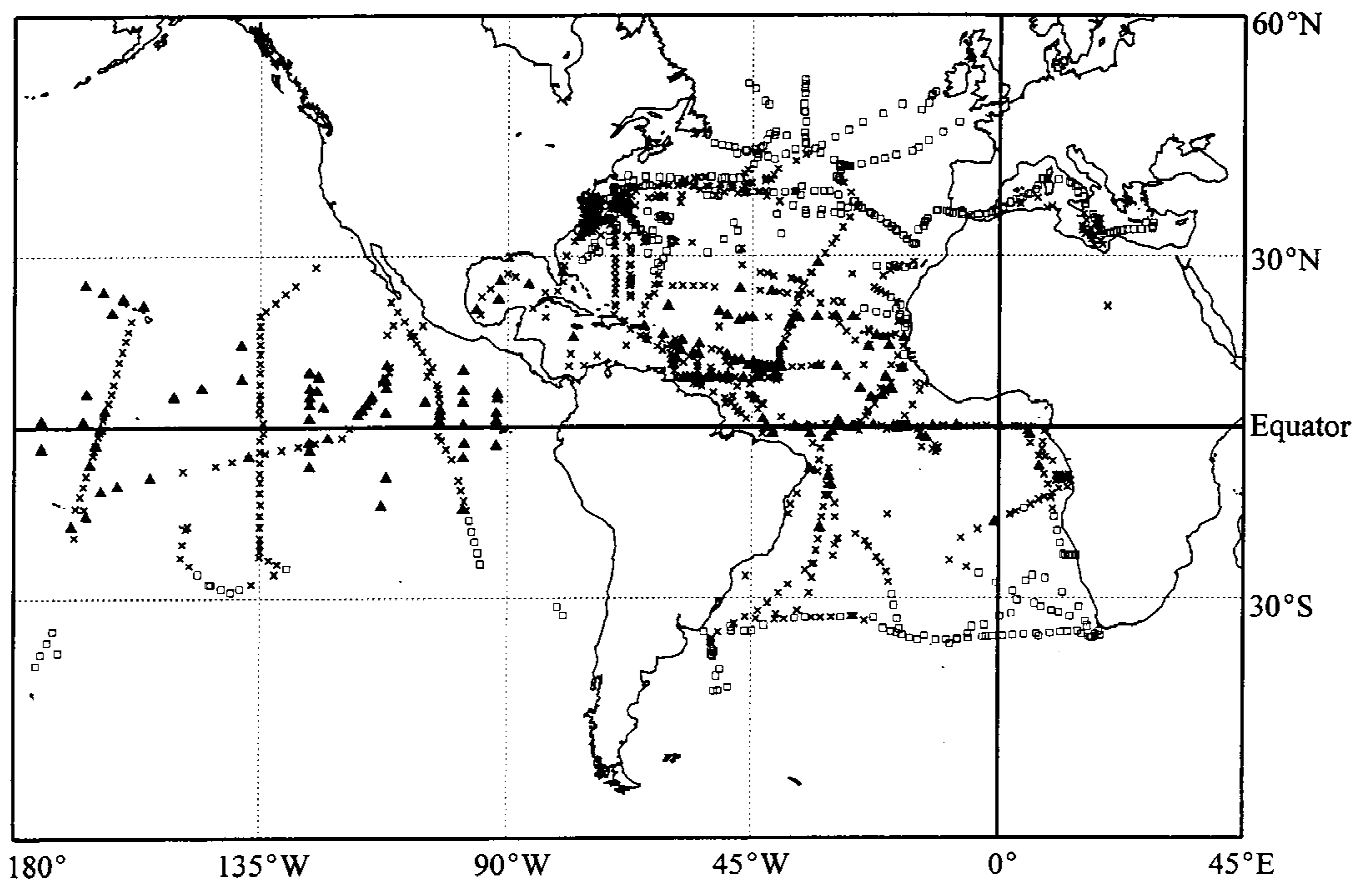

Figure 4. Atlantic and eastern Pacific records of zoanthella larvae, together with negative stations ( $\boldsymbol{\Lambda}$ zoanthellae, $\times$ negative stations with temperature $\geq 22{ }^{\circ} \mathrm{C}, \square$ negative stations with temperature $<22{ }^{\circ} \mathrm{C}$ ).

ginal gastropod shell (Carlgren, 1923; Muirhead et al., 1986); or with the rope-like stems of hyalonematid glass sponges (Schulze, 1887), all of which tend to ensure that specimens are retained in collections. We have collated and analysed records of the geographic and bathymetric distribution of Epizoanthus, partly from the literature but mainly from specimens or information sent earlier to A. Muirhead, or to JSR, and from the substantial collections in the Moscow State Museum, so that these largely new data may be compared with the geographic distributions of Semper's larvae.

\section{Results}

Zoanthellae were obtained at 210 stations and zoanthinae at 79, generally as single larvae but occasionally in greater numbers (rarely $>10$ ) (Fig. 2). The distributions of both larval types were ocean wide but only within warm, essentially tropical waters. There are, however, differences in temperature ranges of the two: zoanthellae were never found at $<22{ }^{\circ} \mathrm{C}$ (Figs 3 and 4 ), whereas substantial numbers of zoanthinae occurred at $18-22{ }^{\circ} \mathrm{C}$ (Figs 3 and 5), with a clearly more northerly distribution in the Atlantic (Fig. 2). The summed occurrences by temperature, tested by the Kolmogorov-Smirnov 2-sample test (Sokal \& Rohlf, 1995), were highly significantly different $(P<0.001)$.

Zoanthellae were commonly $>6$ (maximum 8.6) $\mathrm{mm}$ preserved length, zoanthinae $3-4$ (maximum $5.9) \mathrm{mm}$. Forty three larvae (19 zoanthellae, 24 zoanthinae) were sectioned, though state of preservation, plane of sectioning, and the difficulty in orientating extremely small larvae, made it impossible to obtain all the sought information from every larva. The condition of the mesogloea and cell layers varied in a manner not correlated with size or presence/absence of zooxanthellae. The mesogloea was generally quite thick, and corrugated in some septal pairs; this condition was associated with a thick ectoderm and often with yolk between the septa. In other larvae, the mesogloea was membranous, the ectoderm sparse (in the region of the ciliary band) or missing, and the coelenteron 'empty'. All transversely-sectioned larvae having 12 septa conformed to the brachycnemic pattern (only septal couples 2, 4 and 6 on each side of the directive axis either reaching the actinopharynx or bearing a filament at the centripetal end), with the exception of two that were anomalous. In all, there were three anomalous arrangements: one zoanthina was asymmetrical, with seven perfect and five imperfect 


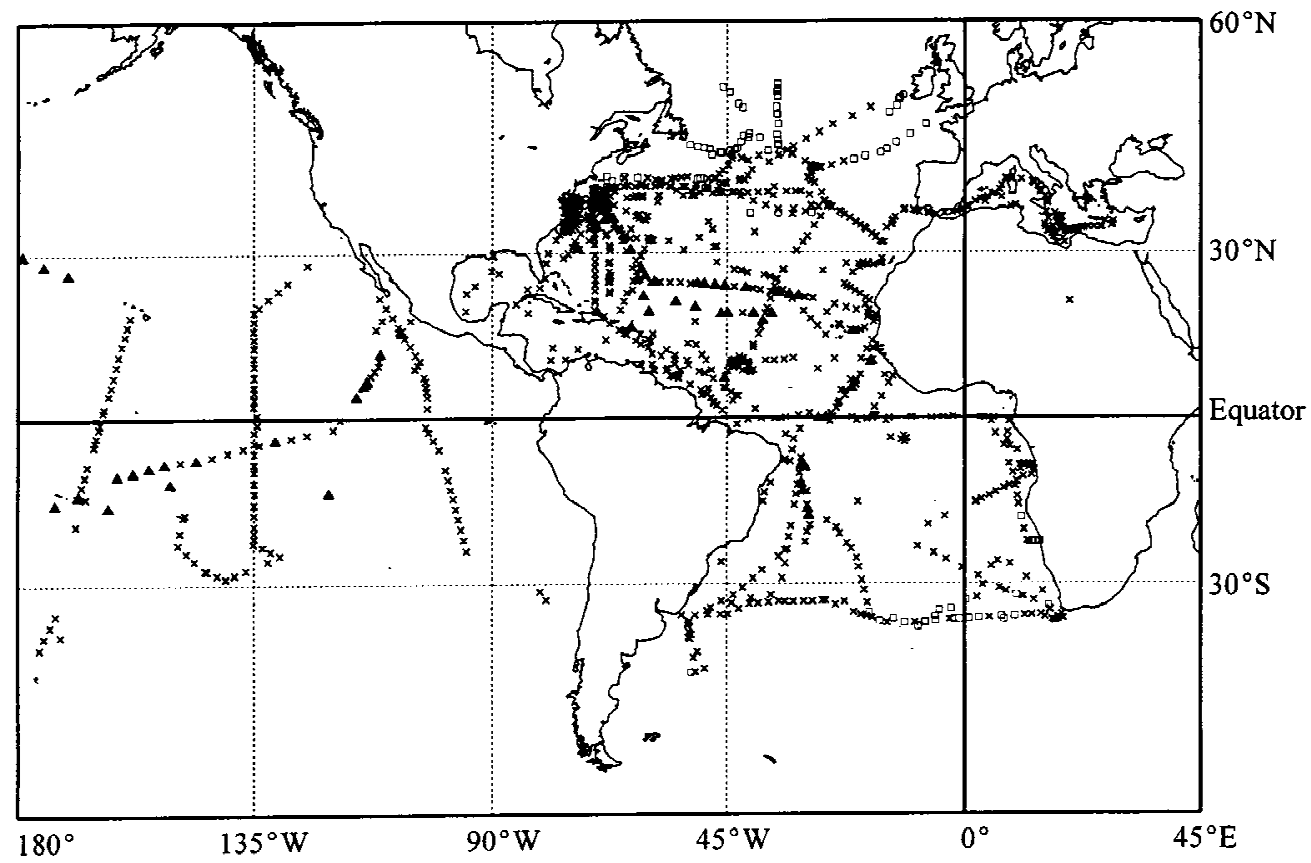

Figure 5. Atlantic and eastern Pacific records of zoanthina larvae, together with negative stations $(\boldsymbol{\Lambda}$ zoanthinae, $\times$ negative stations with temperature $\geq 18{ }^{\circ} \mathrm{C}, \square$ negative stations with temperature $<18{ }^{\circ} \mathrm{C}$ ).

septa; one zoanthina had all 12 septa, except the dorsal directives, perfect; and one zoanthella had 16 septa, 8 of them - including the 1st couple (dorsal directives) - perfect. None had a macrocnemic arrangement and none included smaller, less-developed larvae in the coelenteron (cf. Van Beneden, 1897). Zooxanthellae were present in the endoderm of nine zoanthinae but in none of the zoanthellae. Three larvae, all zoanthinae, contained a small endo-commensal/parasitic amphipod.

We have established that, unlike Semper's larvae, adult Epizoanthus are distributed from the equator to high latitudes (Fig. 6) and also from the intertidal (e.g. E. minutus in Florida (JSR unpublished)) to great depths ( 5000 m) (Fig. 7). While many of the larger species are bathyal or abyssal, there are some which are plentiful in well-studied, shallow seas (e.g. $E$. papillosus in the North Sea, E. couchii around western European coasts, and E. arenaceus in the Adriatic), in depths $<200 \mathrm{~m}$.

\section{Discussion}

That the oceanic distribution of zoanthellae is highly correlated with sea surface temperature was established early in these studies (Scheltema, 1971). What is curious about the present results is the extent to which the temperature limits of zoanthellae and zoanthinae differ. Perhaps a physiological response to temperature limits survival and, therefore, modifies the ocean distribution of larvae, determined initially by their areas of origin and the currents by which they are transported. Nothing known about the geographical distributions and reproductive periods of Palythoa/Protopalythoa and Zoanthus adults (the genera most likely to provide zoanthellae and zoanthinae, respectively) explains this difference. In marginal areas generally (southern Florida, KwaZulu-Natal and southern Queensland), the two groups occur in similar abundances and to similar limits; Protopalythoa occurs in both the Canary Islands and Madeira (Wirtz, 1995) but Zoanthus does not. It, therefore, would be expected a priori that zoanthellae and zoanthinae should occur mixed in broadly constant (though, of course, not necessarily equal) proportions; but this was not so. While some kind of artifact might be suspected, the difference is statistically too significant $(P<0.001)$ to ignore. The fact that the Pacific was relatively undersampled, and that different areas of ocean were visited at different times of year, does not, per se, explain certain areas being dominated by zoanthellae and others by zoanthinae. 


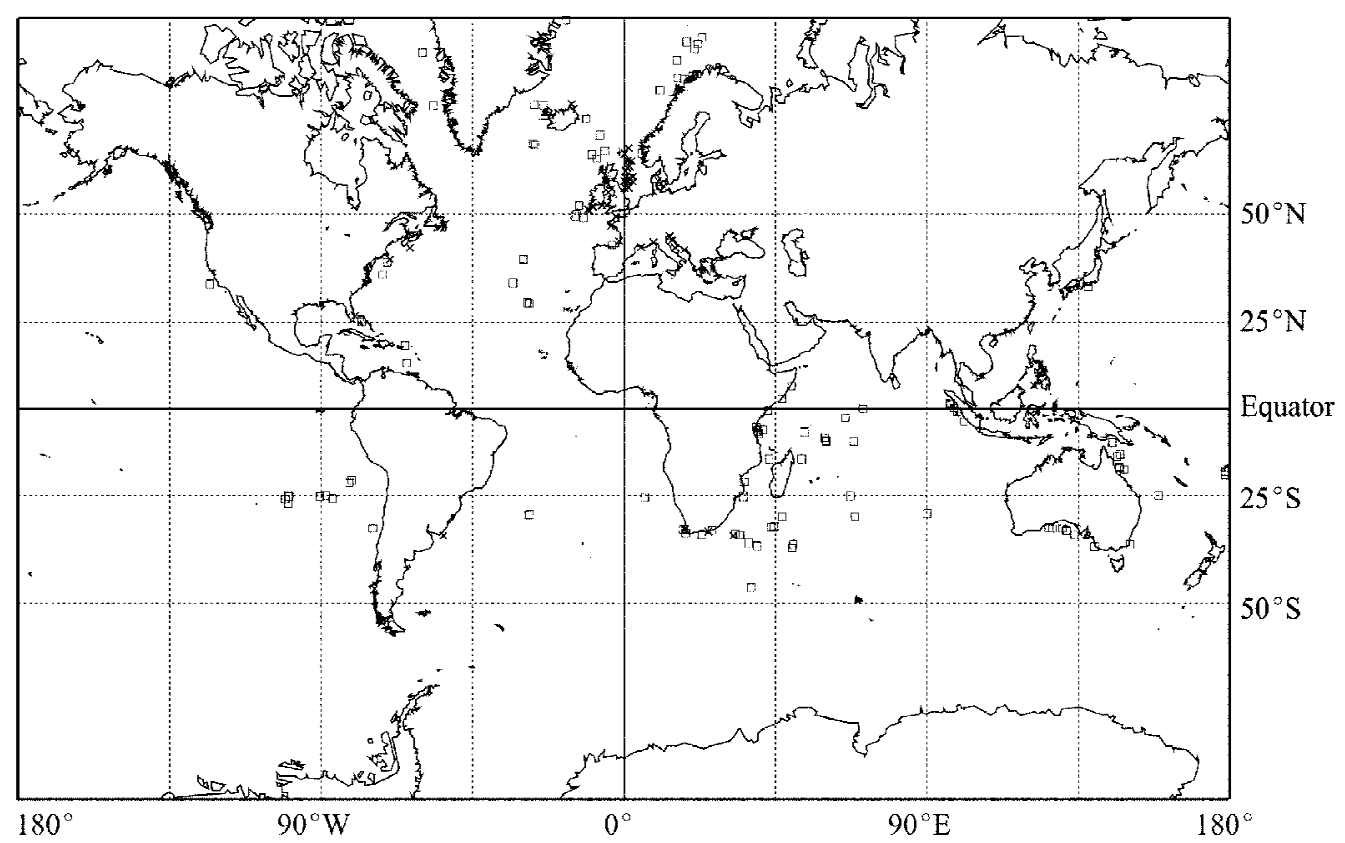

Figure 6. Geographic distribution of the genus Epizoanthus. Data are mainly from unpublished sources (see text) with additional records from Schulze (1887) and Carlgren (1923) $(\square$ stations with depth $<200 \mathrm{~m}, \times$ depth $\geq 200 \mathrm{~m}$ ).

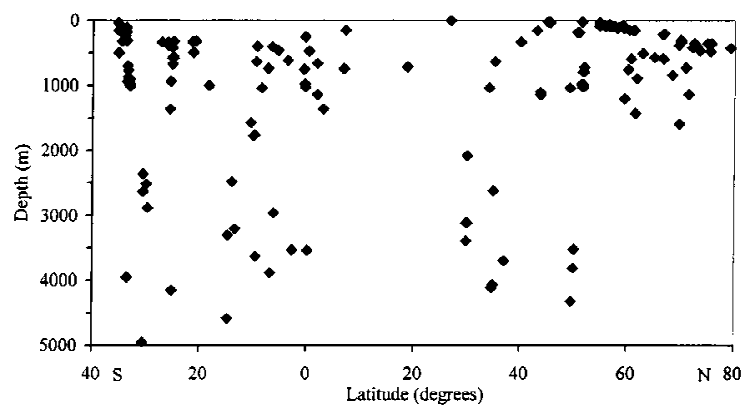

Figure 7. Bathymetric distribution of the genus Epizoanthus. Sources as for Figure 6.

The distribution map (Fig. 2) shows that in the Atlantic ocean, where there are adequate samples, the distributions are correlated with the major surface currents. Zoanthellae dominate at the equator, in the South Equatorial Current (and possibly in the eastwardly-flowing Equatorial Undercurrent below $50 \mathrm{~m}$ depth), through the Caribbean Sea into the Gulf of Mexico, into the Florida Current and also, during the summer months, in the seasonally flowing Equatorial Counter Current as far northeast as the Cape Verde Islands. From $\sim 20^{\circ} \mathrm{N}$, however, zoanthinae prevail in the North Equatorial Current, the Antilles Current, and the outer Gulf Stream east of Cape Hatteras. No larvae, even zoanthinae, occurred in the $20-24{ }^{\circ} \mathrm{C}$ band of Gulf Stream water that flows easterly to the Azores, where the water temperature attenuates rapidly and seasonal differences are quite marked.

In the Pacific, there were fewer larvae, particularly where temperature was also recorded, but clusters of zoanthinae occurred to the west of the Hawaiian chain and around French Polynesia (Fig. 2). The most striking feature of the Pacific distributions is the absence of an eastern Pacific barrier (see Scheltema, 1989), with a notable abundance of zoanthellae east of the Line Islands, despite there being few sources of larvae east of longitude $180^{\circ}$. Many teleplanic larvae of a wide variety of invertebrates retain the ability to metamorphose (Scheltema, unpublished) but Semper's larvae held over several months have never done so. This may be because the requisite cues were absent, but it could also be because the larvae have lost competence. Some of the sectioned larvae appeared in good condition, others appeared 'wasted'. In a recent study on competence and longevity in alyconacean larvae, Zaslow \& Benayahu (1998) found that both zooxanthellate and non-zooxanthellate larvae could survive 7-22 weeks, according to species, but lost competence to metamorphose at 7-11 weeks. In particular, zooxanthellate species, presumably aided by translocated products from photosynthesis, survived for several weeks after 
they had lost competence. It is, therefore, impossible to decide whether teleplanic dispersal of Semper's larvae is adaptive or not (i.e. whether larvae carried in the Equatorial Currents or Countercurrents remain competent to settle after an Atlantic crossing). Unfortunately, the unsatisfactory state of adult zoanthid taxonomy renders meaningful comparison of east and west Atlantic faunas impossible, though the distinctive Isaurus tuberculatus (with a zoanthina) has a pan-tropical distribution (Muirhead \& Ryland, 1985).

It was hoped that, by sectioning a substantial number of larvae, one or more displaying macrocnemic septation would be discovered. This did not happen: all larvae have been brachycnemic or (a few) anomalous. The occurrence of a larva which was brachycnemic on one side of the directive axis and macrocnemic on the other is not surprising, the condition being well-known in adults of brachycnemic genera. Adults with a symmetrical excess of perfect septa must, on the other hand, be unusual and certainly none with perfect dorsal directives has been recorded previously. The absence of macrocnemic larvae, despite the known occurrence of several species of Epizoanthus and Parazoanthus in shallow tropical waters (e.g. West, 1979; Crocker \& Reiswig, 1981), suggests that the fertilized eggs of such zoanthids do not develop into planktonic Semper's larvae.

Our other significant morphological findings concern zooxanthellae. About half the zoanthinae had zooxanthellae in their endoderm, perhaps acquiring them in early development whilst still inshore. It is, in general, not known how larvae and/or adults acquire their zooxanthellae (Ryland, 1997). However, the absence of them from all zoanthellae was unexpected in view of the occurrence of maternal transmission in one species of Protopalythoa well known in the western tropical South Pacific (Ryland \& Babcock, 1991; Burnett et al., 1997) (though the only sampling in this area was a chain of stations (barren of Semper's larvae) between Fiji and New Zealand). Since the largest zoanthid eggs measure $\sim 0.5 \mathrm{~mm}$ diameter, and many are much smaller (Ryland, 1997), Semper's larvae grow considerably, with or without zooxanthellae, providing strong circumstantial evidence that they engulf food through the blastopore/mouth. However, the undamaged small crustaceans present in three zoanthinae appeared not to have been eaten but to be living commensals or endo-parasites. Amphipods have not been recorded as internal commensals of adult zoanthids though they occur in the coelenteron of actinians (Vader, 1983).
Following the absence of macrocnemic larvae in the samples, we surveyed the spatial distribution of adult Epizoanthus for any light it might shed on their larvae. As anticipated, both latitudinal and bathymetric ranges are extensive, in marked contrast to those of brachycnemic genera. Although Isozoanthus giganteus broods embryos (Carlgren, 1923), at least some species of Epizoanthus and Parazoanthus are known to be broadcast spawners (Muirhead et al., 1986; Ryland, unpublished observations, Bermuda, 1999). Whilst the larvae of bathyal and abyssal species may never leave the deep sea (Gage \& Tyler, 1991), not all non-tropical zoanthids are restricted to great depths. Recent surveys have shown Epizoanthus papillosus (=incrustatus) to be abundant in parts of the North and Irish Seas (J.E. Lancaster, J. Ellis, pers. comms) and E. arenaceus is similarly common in the northern Adriatic (Pax \& Müller, 1962; M. Stachowitsch, pers. com.). In both seas, the depths of occurrence are much less than $200 \mathrm{~m}$. Although the North and Adriatic Sea areas were not sampled during our surveys, the former has been intensively studied in the past (Carlgren, 1906; Thorson, 1946; Widersten, 1968). For the Adriatic, after many years of study, Pax \& Müller (1962) concluded that Epizoanthus has no true pelagic stage. Likewise, in northern waters inhabited by Epizoanthus (Fig. 7), no Semper's larvae have been recorded from multi-depth plankton studies (see Murray \& Hjort, 1912). While negative evidence inevitably leaves an element of doubt, Semper's larvae are large and distinctive and it seems probable that, should they occur in the above localities, they would have been recognized by now. The firm conclusion derived from the combined surveys of Semper's larvae and of Epizoanthus adults, therefore, is that macrocnemic zoanthids, as suggested earlier by Menon (1926) and Pax \& Müller (1962), do not reproduce by means of a pelagic zoanthella or zoanthina but by some other, presumably less well differentiated, form of planula which possibly (as the latter authors suggested) never leaves the vicinity of the sea bed. Settlement may even occur before the septa have differentiated, as in the anemone Aiptasia (Widersten, 1968). Without septa, such a planula could not be referred to any particular cnidarian taxon. 


\section{Acknowledgements}

The first author acknowledges a grant from the Leverhulme Trust which enabled him to visit Woods Hole Oceanographic Institution. We thank the following for specimens of, or data on, Epizoanthus: P. Arnold and M. Pichon (Cidaris cruises), P. Arnold and A. Birtles (Cleveland Bay), P.A. Tyler and C.M. Young (Bahamas, Tongue of the Ocean), S. Beaulieu, J. Ellis, S. Jennings, B. Picton and J. Turner. We also acknowledge the constructive comments of two anonymous referees.

\section{References}

Babcock, R. C. \& J. S. Ryland, 1990. Larval development of a tropical zoanthid (Protopalythoa sp.). Invertebr. Reprod. Dev. 17: 229-236.

Burnett, W. J., J. A. H. Benzie, J. A. Beardmore \& J. S. Ryland, 1997. Great Barrier Reef and Torres Straits zoanthids (Cnidaria, Hexacorallia): evolution, systematics and a key to species. Coral Reefs 16: 55-68.

Carlgren, O., 1906. Die Actinien-larven. Nordisches Plankton 11: 65-89.

Carlgren, O., 1923. Ceriantharia und Zoantharia der Deutschen Tiefsee-Expedition. Wiss. Ergebn. dt. Tiefsee-Exped. 'Valdivia' 19(7): 12-89.

Crocker, L. A. \& H. M. Reiswig, 1981. Host specificity in spongeencrusting Zoanthidea (Anthozoa: Zoantharia) of Barbados, West Indies. Mar. Biol. (Berl.) 65: 231-236.

Erdmann, A., 1885. Ueber einige neue Zoantheen. Ein Beitrag zur anatomischen und systematischen Kenntnis der Actinien. Jena. Z. Naturw. 19: 430-488.

Gage, J. \& P. A. Tyler, 1991. Deep-sea Biology: a Natural History of Organisms at the Deep-sea Floor. Cambridge, Cambridge University Press: 504 pp.

Gray, J. E., 1867. Notes on Zoanthinae, with the descriptions of some new genera. Proc. zool. Soc. Lond. 15: 233-240.

Haddon, A. C. \& A. M. Shackleton, 1891. Revision of the British Actiniae, Part II. The Zoantheae. Sci. Trans. r. Dublin Soc. 4: 609-672.

Hertwig, R., 1882. Report on the Actiniaria dredged by H.M.S 'Challenger' during the years 1873-1876. Rep. Sci. Res. 'Challenger' Exped., Zool. 6(15): 1-134.

Kimura, S., Y. Hashimoto \& K. Yamazato, 1972. Toxicity of the zoanthid Palythoa tuberculosa. Toxicon 10: 611-617.

McMurrich, J. P., 1891. Contributions on the morphology of the Actinozoa. III. The phylogeny of the Actinozoa. J. Morphol. 5: 125-164.

Menon, K. R., 1902. Notes on Semper's larvae. Proc. Cambr. Phil. Soc., Biol. Sci. 11: 407-417.

Menon, K. R., 1914. Preliminary note on the metamorphosis of Zoanthella. Rec. Ind. Mus. 10: 212-213.

Menon, K. R., 1926. On the adults of Zoanthella and Zoanthina. Rec. Ind. Mus. 28: 61-64.

Muirhead, A. \& J. S. Ryland, 1985. A review of the genus Isaurus Gray, 1828 (Zoanthidea), including new records from Fiji. J. Nat. Hist. 19: 323-335.
Muirhead, A., P. A. Tyler \& M. H. Thurston, 1986. Reproductive biology and growth of the genus Epizoanthus (Zoanthidea) from the north-east Atlantic. J. mar. biol. Ass. U.K. 66: 131-143.

Murray, J. \& J. Hjort, 1912. The depths of the ocean. London, Macmillan: $821 \mathrm{pp}$

Pax, F. \& I. Müller, 1962. Die Anthozoenfauna der Adria. Fauna et Flora Adriatica. Split, Institut za Oceanografiju i Ribastvo. No. 3: 343 pp.

Ryland, J. S., 1997. Reproduction in Zoanthidea. Invertebr. Reprod. Dev. 31: 177-188.

Ryland, J. S. \& R. C. Babcock, 1991. Annual cycle of gametogenesis and spawning in a tropical zoanthid, Protopalythoa sp. In Williams, R. B. P. F. S. Cornelius, R. G. Hughes \& E. A. Robson (eds), Coelenterate Biology: Recent Research on Cnidaria and Ctenophora. Proceedings of the Fifth International Conference on Coelenterate Biology. Hydrobiologia 216/217: 117-123.

Scheltema, R. S., 1968. Dispersal of larvae by equatorial ocean currents and its importance to the zoogeography of shoal-water tropical species. Nature (Lond.) 217(5134): 1159-1162.

Scheltema, R. S., 1971. The dispersal of the larvae of shoal-water benthic invertebrate species over long distances by ocean currents. In Crisp, D. J. (ed.), Proceedings of the Fourth European Marine Biology Symposium. Cambridge, Cambridge University Press: 7-28.

Scheltema, R. S., 1986. Long-distance dispersal by planktonic larvae of shoal-water benthic invertebrates among Central Pacific islands. Bull. mar. Sci. 39: 241-256.

Scheltema, R. S., 1989. The eastern Pacific as a barrier to the dispersal of planktonic larvae of benthic invertebrates. In Klekowski, R. Z., E. Styczynska-Jurewicz \& L. Falkowski (eds), Proceedings of the 21st European Marine Biology Symposium (1986). Wroclaw, etc., Polish Academy of Sciences: 435-445.

Schulze, F. E., 1887. Report on the Hexactinellida. Rep. Sci. Res. 'Challenger' Exped., Zool. 21: 1-513.

Semper, C., 1867. Ueber einige tropische Larvenformen. Zt. wiss Zool. 17: 407-428.

Sokal, R. R. \& F. J. Rohlf, 1995. Biometry. San Francisco, W.H Freeman: $887 \mathrm{pp}$

Thorson, G., 1946, Reproduction and larval development of Danish marine bottom invertebrates. Medd. Komm. Havundersøg., Kbh., Ser. Plank.,Bd. 4, No. 1: 523 pp.

Vader, W., 1983. Associations between amphipods (Crustacea: Amphipoda) and sea anemones (Anthozoa, Actiniaria). Mem. Austr Mus. 18: 141-153

Van Beneden, E., 1890. Les Anthozoaires pélagiques recueillis par M. le professeur Hensen dans son expédition du plankton. Communication préliminaire. I. - Une larve voisine de la larve de Semper. Archs Biol., Liège 10: 485-521.

Van Beneden, E., 1897. Les Anthozoaires de la 'PlanktonExpedition'. Ergebn. Plankton-Exped. Humboldt Stift. 2 K(e): 485-521.

West, D. A., 1979. Symbiotic zoanthids (Anthozoa: Cnidaria) of Puerto Rico. Bull. mar. Sci. 29: 253-271.

Widersten, B., 1968. On the morphology and development in some cnidarian larvae. Zool. Bidr. Upps. 37: 139-179.

Wirtz, P., 1995. One vascular plant and ten invertebrate species new to the marine flora and fauna of Madeira. Arquipelago. Cienc. Biol. Mar. Mar. Biol. Sci. (13A): 119-123.

Zaslow, R. B.-D. \& Y. Benayahu, 1998. Competence and longevity in planulae of several species of soft corals. Mar. Ecol. Prog. Ser. 163: $235-243$ 